\title{
PENGARUH MODEL PEMBELAJARAN TEAM GAMES TOURNAMENT TERHADAP HASIL BELAJAR IPS SISWA SD
}

\author{
Ira Irviana \\ Administrasi Pendidikan Kehususan Pendidikan Dasar \\ e-mail: irairviana90@yahoo.com
}

\begin{abstract}
The purpose of this study were (i) To see the difference in learning outcomes IPS by using model TGT and lecture method varies (ii) To see the difference in the results of social studies among students' high motivation and low motivation (iii). To see the difference in student learning outcomes IPS high motivation and low motivation in class who use the lecture method varies. (iv) To see the difference in the results of social studies on students 'high motivation class that uses a learning model TGT and lecture method varies (v) To see the difference in the results of social studies on students' low motivation class that uses a learning model TGT and meotode lectures varied, (vi) To see the difference in student learning outcomes IPS high motivation and low motivation in class that uses the TGT learning model, (vii) To see the interaction between the model of learning by learning motivation on learning outcomes IPS.This research is quantitative research types factorial experiment. Techniques of collecting data through tests of student learning outcomes. The population in this study were students of class $V$ of the school year 2014/2015 The samples in this study were taken from two schools, namely Makassar dikecamatan SDN.KIP Maccini and SD Instruction Maccini ie the entire fifth grade students of 60 people from the large number of the population. The result showed that (i) the results of social studies that use learning models TGT higher than the lecture method varies, (ii) the results of social studies on students 'high motivation is higher than the students' low motivation, (iii) The results of social studies students' high motivation is lower than the low motivation of students in classes that use the lecture method varies, (iv) results of social studies groups using learning models TGT higher than in the group that used the lecture method varies on student motivation high, (v) results of social studies groups using learning models TGT more lower than in the group that used the lecture method varies on students 'low motivation, (vi) the results of social studies students' high motivation is higher than the students 'low motivation in the classroom using learning models TGT, (vii) There is an interaction effect between models learning with students' motivation for learning outcomes IPS.
\end{abstract}

Key words: Learning Model TGT, learning outcomes IPS, Eksperimen 2X2, Anova $2 X 2$

\section{ABSTRAK}

Tujuan penelitian ini adalah untuk melihat perbedaan hasil belajar IPS: (1) antara siswa yang menggunakan model pelajaran TGT dan metode ceramah bervariasi, (2) antara siswa yang motivasinya tinggi dan motivasi rendah, (3) antara siswa yang motivasi tinggi dikelas yang menggunakan model pembelajaran TGT dan metode ceramah bervariasi, (4) antara siswa yang motivasi rendah dikelas yang menggunakan model pembelajaran TGT dan metode ceramah bervariasi, (5) antara siswa yang motivasi tinggi dan motivasi rendah dikelas yang menggunakan metode pembelajaran TGT, (6) antara siswa yang motivasinya tinggi dan rendah dikelas yang menggunakan metode ceramah bervariasi, (7) untuk melihat interaktif antara model pembelajaran dengan motivasi belajar terhadap hasil belajar IPS. Penelitian ini merupakan factorial eksperimen $2 \times 2$. Teknik pengumpulan data melalui tes hasil belajar dan angket motivasi belajar, populasi penelitian ini adalah siswa SDN KIP Maccini dan SD Inpres Maccino kelas V tahun ajaran 2014/2015. Sampelnya 60 siswa dari jumlah populasi, data dianalisis dengan Anova 2X2. Hasil analisis data menunjukkan bahwa hasil belajar IPS: (1) Siswa yang 


\begin{abstract}
menggunakan model TGT lebih tinggi dari pada metode ceramah bervariasi, (2) siswa yang motivasinya tinggi lebih tinggi dari pada siswa yang motivasinya rendah, (3) Siswa yang motivasinya tinggi yang diajar dengan model TGT lebih tinggi prestasinya dari pada siswa yang diacara dengan model cerama bervariasi, (4) siswa yang motivasinya rendah lebih tinggi prestasinya jika diajar dengan ceramah bervariasi daripada diajar dengan TGT, (5) siswa yang motivasinya tinggi diajar dengan TGT lebih tinggi hasil belajarnya daripada siswa yang motivasinya rendah, (6) siswa yang motivasinya tinggi lebih rendah prestasinya daripada siswa yang motivasinya rendah jiak diajar dengan ceramah bervariasi, (7) terdapat pengaruh interaktif antara model pembelajar dengan motivasi belajar siswa terhadap hasil belajar IPS.
\end{abstract}

Kata Kunci: Model Pembelajaran TGT, Hasil belajar IPS, Eksperimen 2X2, Anova 2X2

\section{PENDAHULUAN}

Dalam lingkup pendidikan terdapat proses belajar mengajar yang dapat berpengaruh kepada sikap dan kemampuan intelektual anak. Dalam cakupan ini salah satu mata pelajaran yang dapat membantu anak mengembangkan sikap ilmiah adalah pembelajaran IPS SD. Suryosubroto (2012:29) menyatkan bahwa "kemampuan mengelola proses belajar mengajar adalah kesanggupan atau kecakapan para guru dalam menciptakan suasana komunikasi yang eduktif, antara guru dan siswa yang mencakup ranah kognitif, efektif, dan pisikomotorik, sebagai sebagai upaya mempelajari sesatu berdasarkan perencanaan sampai dengan tahap evaluasi dan tindak lanjut hingga teercapai tujuan pembelajaran."

Para guru sering kali menyampaikan materi hanya dengan ceramah, sehingga pembelajaran IPS cenderung membosankan dan kurang menarik minat para siswa yang para gilirannya prestasi belajar siswa kurang memuaskan. Di sisi lain juga ada kecenderungan bahwa aktifitas siswa dalam pembelajaran IPS masih rendah. Setidaknya ada tiga indikator yang menunjkkan hal ini. Pertama, siswa kurang memiliki keberanian untuk menyampaikan pendapat kepada orang lain. Kedua, siswa kurang memiliki kemampuan untuk merumuskan gagasan sendiri. Dan ketiga, siswa belum terbiasa bersaing menyampaikan pendapat dengan teman yang lain. Ketiga hal tersebut sangat dipengaruhi oleh motivasi belajar siswa.

Fakta di lapangan yang menunjukkan bahwa masih ada sebagian siswa yang kurang memahami konsep yang ada pada pembelajaran IPS.Berdasarkan hasil pengamatan dan informasi yang diperoleh di SDN. KIP Maccini ditemukan bahwa pengalaman guru dalam mengajarkan IPS selama ini masih banyak siswa mengalami kesulitan memahami konsep pembelajaran IPS. Kesulitan ini dapat disebabkan antara lain oleh model dan strategi pembelajaran yang digunakan kurang melibatkan siswa. Hal yang menjadi hambatan selama ini dalam pembelajaran IPS adalah disebabkan kurang dikemasnya pembalajaran IPS yang menarik, menantang, dan menyenangkan sehingga kurang termotivasi dalam proses pembelajaran.

Salah satu tipe dalam pembelajaran kooperatif yang dianggap peneliti dapat memotivasi siswa untuk berperan aktif dan juga menyenangkan dalam proses belajar-mengajar adalah model pembelajaran kooperatif tipe Teams-Games-Tournament (TGT).

Berdasarkan analisis diatas maka peneliti ingin mengetahui lebih jauh tentang sejauh mana pengaruh model pembelajaran TGT terhadap hasil belajar siswa sekolah dasar serta sejauh mana peran motivasi dalam pembelajaran untuk mewujudkan hasil belajar siswa yang lebih baik. Maka peneliti meruuskan rumusan masalah sebagai berikut : (1) Untuk menunjukkan perbedaan hasil belajar IPS dengan menggunakan model pembelajaran TGT dan metode ceramah bervariasi, (2) menunjukkan perbedaan hasil belajar IPS antara siswa motivasi tinggi dan motivasi rendah, (3) Untuk menunjukkan interaksi antara model pembelajaran dengan motivasi belajar terhadap hasil belajar IPS, (4) Untuk menunjukkan perbedaan hasil belajar IPS pada siswa motivasi tinggi dikelas yang menggunakan model pembelajaran TGT dan metode ceramah bervariasi, (5) Untuk menunjukkan perbedaan hasil belajar IPS pada siswa motivasi rendah dikelas yang menggunakan model pembelajaran TGT dan meotode ceramah bervariasi, (6) Untuk menunjukkan perbedaan hasil belajar IPS pada 
siswa motivasi tinggi dan motivasi rendah dikelas yang menggunakan model pembelajaran TGT,(7) Untuk menunjukkan perbedaan hasil belajar IPS pada siswa motivasi tinggi dan motivasi rendah dikelas yang menggunakan metode ceramah bervariasi.

Pembelajaran kooperatif tipe TGT adalah suatu pembelajaran dimana setelah kehadiran guru, siswa pindah ke kelompoknya masing-masing untuk saling membantu menjawab pertanyaan-pertanyaan dari materi yang diberikan. Setiap siswa akan bertemu pada meja turnamen untuk berlomba. Mereka menjawab satu pertanyaan yang sama yang telah dibahas bersama-sama dalam kelompoknya. Dengan cara ini setiap siswa berkesempatan menyumbangkan skor sebanyak-banyaknya untuk kelompoknya. Kelompok yang memiliki skor tertinggi itulah yang menjadi pemenang turnamen.

Sriyono (2011:210) mengemukakan tujuan suatu model permainan dalam proses pembelajaran, diantaranya sebagai berikut: (1) Siswa senang dalam mengerjakan suatu bahan pelajaran, (2) Siswa terdorong dan menaruh minat untuk mempelajari suatu bahan pelajaran, (3) Adanya suatu semangat bertanding dalam suatu permainan dan berusaha untuk menjadi pemenang dapat mendorong siswa untuk memusatkan perhatian pada permainan yang dihadapi, (4) Jika siswa terlibat pada kegiatan dan keaktifan mengerjakan sendiri dan memecahkan sendiri, mereka akan betul-betul memahami dan mengerti, (5) Keteganganketegangan dalam pikiran siswa dapat dikurangi, (6) Siswa dapat memanfaatkan waktu yang terulang.

Adapun tahap-tahap (skenario) yang perlu diperhatikan dalam pembelajaran kooperatif tipe TGT, menurut Suradi (2010:9) adalah sebagai berikut: (1) Pembentukan kelompok, (2) Pemberian materi, (3) Belajar kelompok, (4) Turnamen, (5) Skor individu, (6) Skor kelompok, (6) Penghargaan.

Menurut Slavin (dalam Hock, 2012:1), mengemukakan langkah-langkah dalam pelaksanaan TGT adalah sebagai berikut: (1) Guru mengajar seperti biasa, (2) Siswa belajar dalam kelompok heterogen, (3) Siswa pergi ke meja pertandingan masing-masing untuk bertanding. Setiap meja pertandingan terdiri dari seorang siswa dari setiap kelompok yang sama tahap pencapaiannya, (4) Setelah selesai pertandingan, semua siswa kembali ke kelompok masing-masing. Skor setiap siswa dijumlahkan untuk mendapatkan skor kelompok, (5) Guru mengumumkan skor-skor kelompok dan memberi penghargaan kepada kelompok yang menjadi juara.

Menurut teori Gestalt, belajar merupakan suatu proses perkembangan. Artinya bahwa secara kodrati jiwa raga anak mengalami perkembangan. Perkembangan sendiri memerlukan sesuatu baik yang berasal dari diri siswa sendiri maupun dari lingkungannya. Berdasarkan teori ini hasil belajar siswa dipengaruhi oleh dua hal, siswa itu sendiri dan lingkungannya.Pertama, siswa; dalam arti kemampuan berpikir atau tingkah intelektual, motivasi, minat, dan kesiapan siswa, baik jasmani maupun rohani. Kedua, lingkungan; yaitu sarana dan prasarana, kompetensi guru, kreativitas guru, sumber-sumber belajar, metode serta dukungan lingkungan, keluarga, dan lingkungan.

Pendapat yang senada dikemukakan oleh Wasliman (2012: 158), hasil belajar yang dicapai oleh siswa merupakan hasil interaksi antara berabagai faktor yang memepengaruhi, baik faktor internal maupun eksternal. berikut:

Tujuan dari penelitian ini adalah sebagai

1. Untuk menunjukkan perbedaan hasil belajar IPS dengan menggunakan model pembelajaran TGT dan metode ceramah bervariasi.

2. Untuk menunjukkan perbedaan hasil belajar IPS antara siswa motivasi tinggi dan motivasi rendah.

3. Untuk menunjukkan perbedaan hasil belajar IPS pada siswa motivasi tinggi dikelas yang menggunakan model pembelajaran TGT dan metode ceramah bervariasi.

4. Untuk menunjukkan perbedaan hasil belajar IPS pada siswa motivasi rendah dikelas yang menggunakan model pembelajaran TGT dan meotode ceramah bervariasi.

5. Untuk menunjukkan perbedaan hasil belajar IPS pada siswa motivasi tinggi dan motivasi rendah dikelas yang menggunakan model pembelajaran TGT ?

6. Untuk menunjukkan perbedaan hasil belajar IPS pada siswa motivasi tinggi dan motivasi rendah dikelas yang menggunakan metode ceramah bervariasi.

7. Untuk menunjukkan interaksi antara model pembelajaran dengan motivasi belajar terhadap hasil belajar IPS. 
Hipotesis penelitian ini adalah:

1. Terdapat perbedaan hasil belajar IPS yang menggunakan model pembelajaran TGT dan metode ceramah bervariasi.

2. Terdapat perbedaan hasil belajar IPS pada siswa motivasi tinggi dan siswa motivasi rendah.

3. Terdapat Perbedaan hasil belajar IPS kelompok yang menggunakan model pembelajaran TGT dan kelompok yang menggunakan metode ceramah bervariasi pada siswa motivasi tinggi.

4. Terdapat perbedaan hasil belajar IPS kelompok yang menggunakan model pembelajaran TGT dan kelompok yang menggunakan metode ceramah bervariasi pada siswa motivasi rendah.

5. Terdapat perbedaan hasil belajar IPS siswa motivasi tinggi dan siswa motivasi rendah pada kelas yang menggunakan model pembelajaran TGT.

6. Terdapat perbedaan hasil belajar IPS siswa motivasi tinggi dan siswa motivasi rendah pada kelas yang menggunakan metode ceramah bervariasi.

7. Terdapat interaksi antara model pembelajaran dengan motivasi belajar siswa terhadap hasil belajar IPS (INT A X B).

\section{METODE PENELITIAN}

\section{Lokasi dan Jenis Penelitian}

Penelitian bertempat di SDN KIP Maccini dan SD Inpres Maccini di kecamatan Makassar Kota Makassar. Berdasarkan rumusan masalah penelitian, maka penelitian ini dikategorikan ke dalam penelitian eksperimen dengan rancangan faktorial 2X2. Dimana rancangan factorial $2 X 2$ merupakan modifikasi dari rancangan true eksperimen yaitu dengan memperlihatkan kemungkinan adanya variable moderator yang mempengaruhi perlakuan variable bebas terhadap variable terikat. Metode penelitian eksperimen dapat diartikan sebagai metode penelitian yang digunakan untuk mencari pengaruh perlakuan tertentu terhadap yang lain dalam kodisi yang terkendali. Metode eksperimen dengan variabel bebas adalah variabel perlakuan model pembelajaran TGT (Team Games Tournament) (X).Penelitian ini dilakukan perlakuan untuk mencari pengaruh diantara kedua variabel hasil belajar $(\mathrm{Y})$ dan motivasi belajar sebagai variabel moderator.

Pada penelitian ini subjek diberi perlakuan yang berbeda. Kelas pertama menggunakan model pembelajaran TGT (Team Games Tournament) dan kelas ke dua dengan metode ceramah bervariasi, kemudian diadakan pengamatan terhadap gejala-gejala yang muncul akibat perlakuan. Perlakuan yang dimaksud adalah pembelajaran IPS dengan model TGT (Team Games Tournament) dan pembelajaran IPS dengan metode ceramah bervariasi.

Gejala yang akan diselidiki dalam penelitian eksperimen, adalah:

1. Perbedaan hasil belajar IPS siswa yang mengikuti pembelajaran dengan model TGT dan hasil belajar IPS siswa yang mengikuti pembelajaran dengan metode ceramah bervariasi. Hal ini untuk menjawab rumusan masalah utama penelitian ini.

2. Beberapa hal yang berkaitan dengan pembelajaran IPS melalui model TGT dan metode ceramah, yaitu bagaimana motivasi siswa dengan penyajian model TGT dan motivasi dengan penyajian metode ceramah bervariasi, Hal ini untuk menjawab beberapa pertanyaan penelitian.

\section{Populasi dan Sampel}

Populasi ini adalah seluruh siswa kelas V yang berada di Kecamatan Makassar yang berjumlah 1885 pada tahun ajaran 2014/2015 yang terdiri. Sampel adalah sejumlah anggota yang dipilih atau diambil dari suatu populasi.

Teknik penarikan sampel dari suatu populasi mengacu pada situasi dan karakteristik sekolah tersebut yang tidak jauh berbeda dengan sekolah lainnya yang memiliki kesempatan yang sama untuk sebagai sampel. Ini berarti bahwa teknik penarikan sampel yang digunakan dalam penelitian ini memiliki karakteristik yang sama. Metode pengambilan sampel diperoleh dengan menggunakan multistage sampling dengan teknik purposive sampling. Untuk menentukan teknik multistage sampling, Handini (2012) mengemukakan bahwa multistage sampling yaitu populasi dibagi menjadi kelompok-kelompok yang disebut sebagai kelompok primer kemudian ditarik sampel kelompok primer, dari sampel kelompok primer dibagi menjadi kelompok sekunder, kemudian ditarik sampel kelompok sekunder dengan metode sampling banyaknya tahapan untuk menentukan sampel. Penentuan 
sampel dalam penelitian ini diambil dari dua sekolah dikecamatan Makassar yaitu SDN.KIP Maccini dan SD Inpres Maccini yaitu siswa kelas $\mathrm{V}$ yang keseluruhan berjumlah 64 orang dari banyaknya jumlah populasi.Selanjutnya dites motivasi belajar siswa pada kelas kontrol dan kelas eksperimen kemudian menentukan kelompok kelas atas dan kelompok bawah.

Kelly mengemukakan untuk menetapkan kelompok atas dan kelompok bawah yang tepat dimulai dari $25 \%$ sampai dengan $33 \%$ dengan menggunakan teknik purposive sampling. Untuk menentukan kelompok sel sampel terlebih dahulu merengking siswa berdasarkan hasil tes motivasi yang diperoleh dan diambil $31 \%$ dari 60 orang untuk kelompok siswa motivasi tinggi sebanyak $19,84 \%$ atau 15 orang dan kelompok siswa motivasi rendah sebanyak $19,84 \%$ atau 15 orang. Dengan demikian terbentuklah masingmasing 15 sel sampel kelompok belajar IPS motivasi tinggi dan motivasi rendah.Sehingga sampel dalam penelitian ini berjumlah 30 orang.

Untuk membagi kelompok siswa motivasi tinggi pada mata pelajaran IPS digunakan Teknik Maching Ordinal Pairing (MOP), sebagai berikut:

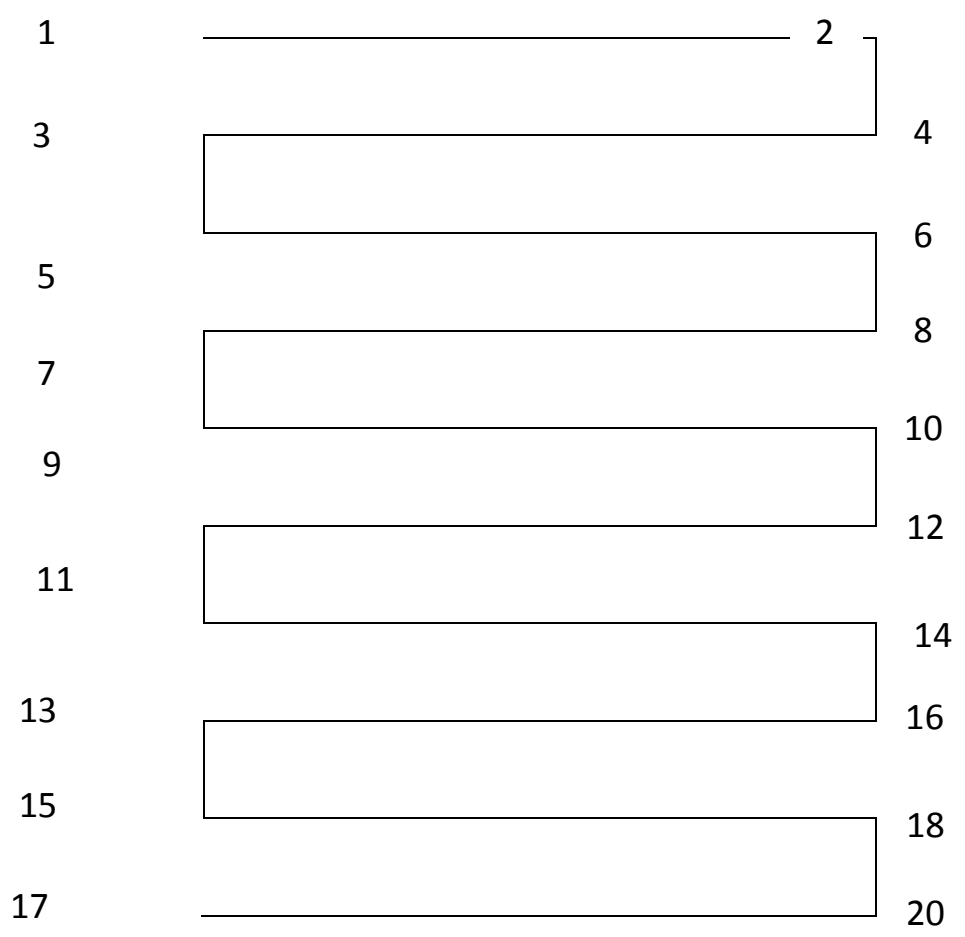

Gambar 3.1 : Teknik pembagian kelompok motivasi tinggi (Djaali,2010:3)

Untuk membagi kelompok siswa motivasi rendah pada mata pelajaran IPS digunakan Teknik Maching Ordinal Pairing (MOP), sebagai berikut: 


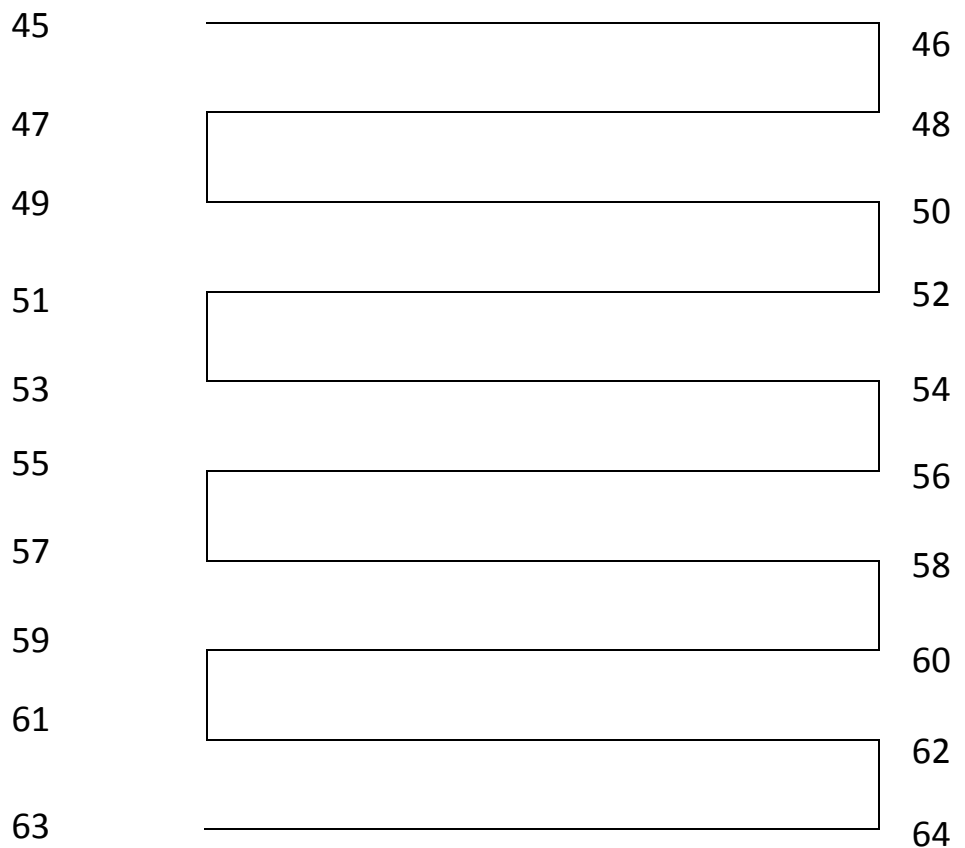

Gambar 3.1 : Teknik pembagian kelompok motivasi rendah (Djaali, 2010:3).

Dengan demikian terbentuklah empat sel dari kedua kelompok model pembelajaran TGT yakni : (1) A1B1 = Kelompok model pembelajaran TGT pada motivasi tinggi sebanyak 15 orang, (2) A2B1 = Kelompok pembelajaran metode ceramahpada motivasi tinggi sebanyak 15 orang, (3) A1B2 = Kelompok model pembelajaran TGT pada motivasi rendahsebanyak 15 orang, (4) A2B2 = Kelompok pembelajaran metode ceramah pada motivasi rendah sebanyak 15 orang. Adapun pengelompokan sampel untuk setiap kelompok tampak pada table 3.2 sebagai berikut:

Table 3.2 Banyak sampel untuk setiap kelompok

\begin{tabular}{c|c|c|c}
\hline Model & $\begin{array}{c}\text { TGT } \\
\left(\mathbf{A}_{1}\right)\end{array}$ & $\begin{array}{c}\text { Metode Ceramah } \\
\text { Bervariasi } \\
\left(\mathbf{A}_{2}\right)\end{array}$ & Total \\
\hline $\begin{array}{c}\text { Motivasi } \\
\left(\mathrm{B}_{1)}\right.\end{array}$ & 15 & 15 & 30 \\
\hline $\begin{array}{c}\text { Rendah } \\
\left(\mathrm{B}_{2)}\right.\end{array}$ & 15 & 15 & 30 \\
\hline Total & 30 & 30 & 60 \\
\hline
\end{tabular}

Keterangan :

A1B1 = Sebanyak 15 orang yang memiliki motivasi tinggi dengan menggunakan model pembelajaran TGT

$\mathrm{A} 2 \mathrm{~B} 1$ = Sebanyak 15 orang yang memiliki motivasi tinggi dengan menggunakan metode ceramah bervariasi

A1B2 = Sebanyak 15 orang yang memiliki motivasi rendah dengan menggunakan model pembelajaran TGT

$\mathrm{A} 2 \mathrm{~B} 2$ = Sebanyak 15 orang yang memiliki motivasi rendah dengan menggunakan metode ceramah bervariasi

\section{Variabel penelitian}

Variabel bebas dalam penelitian ini adalah penggunaan model pembelajaran TGT dalam pembelajaran IPS. 
Variabel terikat dalam penelitian ini adalah penguasaan IPS siswa melalui hasil belajar yang dicapai setelah siswa diberi perlakuan. Hasil belajar yang dimaksud adalah tingkat pencapaian belajar yang diukur dengan tes hasil belajar.
Variabel moderator dalam penelitian ini adalah motivasi belajar IPS siswa yang diukur dengan angket motivasi belajar.

\section{Rancangan penelitian}

Adapun rancangan penelitian yang digunakan adalah desain faktorial $2 \mathrm{X} 2$ seperti terlihat pada tabel berikut :

\begin{tabular}{c|c|c|c}
\hline & $\mathrm{A}_{1}$ & $\mathrm{~A}_{2}$ & $\mathrm{~T}$ \\
\hline $\mathrm{B}_{1}$ & $\mathrm{~A}_{1} \mathrm{~B}_{1}$ & $\mathrm{~A}_{2} \mathrm{~B}_{1}$ & $\mathrm{~T}_{3}$ \\
\hline $\mathrm{B}_{2}$ & $\mathrm{~A}_{1} \mathrm{~B}_{2}$ & $\mathrm{~A}_{2} \mathrm{~B}_{2}$ & $\mathrm{~T}_{4}$ \\
\hline $\mathrm{T}$ & $\mathrm{T}_{1}$ & $\mathrm{~T}_{2}$ & $\mathrm{Y}$ \\
\hline
\end{tabular}

Keterangan:

$$
\begin{aligned}
& \mathrm{A}_{1}=\text { Perlakuan yaitu pembelajaran IPS } \\
& \mathrm{A}_{2} \quad=\text { Perlakuan yaitu pembelajaran IPS } \\
& \text { dengan metode ceramah } \\
& \mathrm{B}_{1} \quad=\text { Motivasi Tinggi } \\
& \mathrm{B}_{2}=\text { Motivasi Rendah } \\
& \mathrm{A}_{1} \mathrm{~B}_{1}=\text { Motivasi tinggi dikelas yang } \\
& \text { diterapkan model pembelajaran TGT } \\
& \mathrm{A}_{2} \mathrm{~B}_{1}=\text { Motivasi tinggi dikelas yang } \\
& \text { diterapkan metode ceramah } \\
& \mathrm{A}_{1} \mathrm{~B}_{2}=\text { Motivasi rendah dikelas yang } \\
& \text { diterapkan model pembelajaran TGT } \\
& \mathrm{A}_{2} \mathrm{~B}_{2}=\text { Motivasi rendah dikelas yang } \\
& \text { diterapkan metode ceramah } \\
& \mathrm{Y}=\text { Hasil belajar siswa }
\end{aligned}
$$

\section{Definisi Operasional Variabel}

Beberapa pengertian yang dapat dijelaskan dan menjadi batasan definisi operasional variabel dalam penelitian ini antara lain sebagai berikut:

1. TGT (Team Games Tournament) adalah suatu pembelajaran dimana setelah kehadiran guru, siswa pindah ke kelompoknya masingmasing untuk saling membantu menjawab pertanyaan-pertanyaan dari materi yang diberikan. Setiap siswa akan bertemu pada meja turnamen untuk berlomba. Mereka menjawab satu pertanyaan yang sama yang telah dibahas bersama-sama dalam kelompoknya. Dengan cara ini setiap siswa berkesempatan menyumbangkan skor sebanyak-banyaknya untuk kelompoknya. Kelompok yang memiliki skor tertinggi itulah yang menjadi pemenang turnamen. Adapun tahap-tahap (skenario) yang perlu diperhatikan dalam pembelajaran kooperatif tipe TGT adalah Pembentukan kelompok, Pemberian materi, Belajar kelompok, Turnamen, Skor individu, Skor kelompok, Penghargaan.

2. Motivasi dalam pembelajaran dapat dikatakan sebagai daya penggerak dari dalam dan di dalam subjek untuk melakukan aktivitas-aktivitas tertentu demi mencapai suatu tujuan.

3. Hasil belajar dapat diartikan sebagai tingkat keberhasilan siswa dalam mempelajari materi pelajaran disekolah yang dinyatakan dalam skor yang diperoleh dari hasil tes mengenal sejumlah materi pelajaran tertentu. Secara sederhana, yang dimaksud dengan hasil belajar siswa adalah kemampuan yang diperoleh anak setelah melalui kegiatan belajar.

\section{Teknik Pengumpulan Data}

Teknik pengumpulan data penelitian ini menjelaskan jenis-jenis instrumen dan skala pengukuran yang digunakan, serta tahapantahapan pengembangan instrumen yang mencakup: definisi konseptual, definisi oprasional, kisi-kisi instrumen, proses validasi konsep, pengujian validitas dan perhitungan reliabilitas.

1. Instrumen Variabel Terikat

Variabel terikat dalam penelitian ini adalah hasil belajar IPS siswa.

a. Definisi Konseptual

Hasil belajar IPS adalah suatu pola perubahan tingkah laku dalam diri seseorang dalam mencapai ilmu pengetahuan yang didasari pengamatan yang mengukur aspek pada rasa 
ingin tahu mengenai kehidupan sosial masyarakat.

b. Definisi Oprasional

Hasil belajar IPS adalah hasil tes kemampuan belajar IPS yang mengukur aspek (1) rasa ingin tahu mengenai ilmu sosial, (2) peristiwa sosial masyarakat.

c. Kisi-Kisi Instrumen

Penelitian ini menyajikan kisi-kisi instrumen berdasarkan definisi konseptual.Kisikisi instrumen disajikan dalam bentuk tabel yang berisikan dimensi, indikator, nomor butir dan jumlah butir untuk setiap indikator yang diukur.Kisi-kisi instrumen berupa butir soal tes hasil belajar IPS siswa.

d. Proses Validasi Konsep

Adapun proses validasi konsep instrumen penelitian hasil belajar IPS siswa diperiksa melalui uji pakar ahli yang memiliki wawasan keilmuan tentang hasil belajar IPS sehingga konsep instrumen hasil belajar IPS dapat dipercaya dan dapat diuji cobakan dalam penelitian ini.

e. Pengujian Validitas dan Perhitungan

Reliabilitas

Uji validitas dengan menggunakan rumus

Poin Biseral dengan rumus sebagai berikut :

$$
r_{p b i}=\frac{M_{p}-M_{q}}{S_{t}} \sqrt{p q}
$$

Perhitungan Reliabilitas

Uji realibilitas dengan menggunakan rumus Kuder Richardson yaitu KR-20 dengan rumus sebagai berikut:

Keterangan:

$$
\mathrm{r}_{11}=\left(\frac{n}{n-1}\right)\left(\frac{s^{2}-\sum p q}{s^{2}}\right)
$$

$\mathrm{s}=$ standar deviasi skor total

$\mathrm{p}=$ proporsi siswa yang menjawab benar untuk tiap-tiap item

$\mathrm{q}=$ proporsi siswa yang menjawab salah untuk tiap-tiap item

\section{f. Instrumen Variabel Moderator}

Variabel moderator dalam hal ini adalah motivasi belajar IPS siswa.Dimana instrument yang digunakan adalah angket motivasi belajar dengan penggunaan skala likert.Angket siswa terhadap kelompok yang diberi perlakuan model pembelajaran TGT (Team Games Tournament) dan yang diberi perlakuan metode ceramah bervariasi. Angket ini disusun untuk memperolah gambaran mengenai respons siswa terhadap materi pembelajaran.Motivasi belajar siswa yang meliputi perhatian terhadap pelajaran (attention), keterkaitan (relevance), keyakinan diri (confidence), dan kepuasan (satisfaction).Dimana pengisian skala likert dengan memberi 30 pertanyaan kepada siswa dengan memilih jawaban selalu, sering, kadang-kadang, jarang dan tidak pernah.

\section{Teknik Analisis Data}

Data yang diperoleh dianalisis dengan menggunakan analisis deskriftif dan inferensial

\section{a. Statistik Deskriptif}

Statistik deskriptif adalah statistik yang berfungsi untuk mendeskripsikan atau memberi gambaran terhadap objek yang diteliti melalui data sampel atau populasi sebagaimana adanya, tanpa melakukan analisis dan membuat kesimpulan yang berlaku untuk umum.

\section{b. Statistik Inferensial}

Statistik inferensial adalah berhubungan dengan metode perampatan (generalization) informasi, atau secara lebih khusus dengan menarik kesimpulan tentang populasi yang didasarkan pada sampel yang ditarik dari populasinya.Menurut Handini (2012), Statistik inferensial merupakan cara yang digunakan untuk menarik kesimpulan atau memprediksi atau mengestimasi karakteristik populasi melalui karakteristik sampel yang terpilih dari populasi tersebut. Dari pendapat diatas dapat disimpulkan bahwa statistik inferensial adalah sesuatu yang berupa informasi atau data yang dapat ditarik kesimpulan dari populasi melalui sampel yang terpilih dari populasi tersebut.

Uji Persyaratan Analisis statistik inferensial digunakan Uji normalitas dan homogenitas. Uji normalitas adalah salah satu persyaratan dalam pengujian hipotesis pada statistik inferensial. Menurut Kadir (2010), Uji normalitas distribusi data menggunakan uji Lelliefors adalah untuk mengetahui apakah data dari masing-masing kelompok berdistribusi normal atau tidak.Salah satu kelebihan uji normalitas ini adalah untuk menghitung kenormalan data $\mathrm{Y}$ untuk kelompok $\mathrm{A}_{1}, \mathrm{~A}_{2}, \mathrm{~B}_{1}$, $\mathrm{B}_{2}, \mathrm{~A}_{1} \mathrm{~B}_{1}, \mathrm{~A}_{1} \mathrm{~B}_{2}, \mathrm{~A}_{2} \mathrm{~B}_{1}, \mathrm{~A}_{2} \mathrm{~B}_{2}$.

Perhitungan analisis Uji Normalitas distribusi data menggunakan Uji Lilliefors sebagai berikut : (1) Untuk kelompok $\left(\mathrm{A}_{1}\right)$ model pembelajaran TGT, (2) Untuk kelompok $\left(\mathrm{A}_{2}\right)$ 
metode ceramah bervariasi, (3) untuk kelompok $\left(\mathrm{A}_{1} \mathrm{~B}_{1}\right)$ perlakuan model pembelajaran TGT pada siswa motivasi tinggi, (4) untuk kelompok $\left(A_{1} B_{2}\right)$ untuk perlakuan model pembelajaran TGT pada siswa motivasi rendah, (5) untuk kelompok $\left(\mathrm{A}_{2} \mathrm{~B}_{1}\right)$ perlakuan motode ceramah bervariasi pada siswa motivasi tinggi, (6) untuk kelompok $\left(\mathrm{A}_{2} \mathrm{~B}_{2}\right)$ perlakuan metode ceramah bervariasi pada siswa motivasi rendah. Jika hasil pengujian menunjukkan $\mathrm{L}_{\text {hitung }}<\mathrm{L}_{\text {tabel }}$ maka data distribusi normal.

Uji homogenitas ini adalah salah satu persyaratan dalam pengujian hipotesis pada statistik inferensial. Menurut Kadir (2010), uji homogenitas distribusi data menggunakan uji Bartlett adalah untuk mengetahui apakah data tersebut homogen atau tidak homogen pada taraf $\alpha=0,05$. Salah satu kelebihan uji homogenitas ini adalah untuk menghitung homogenitas data $\mathrm{Y}$ untuk kelompok $A_{1}$ dan $A_{2}$, kelompok $B_{1}$ dan $B_{2}$, kelompok $\mathrm{A}_{1} \mathrm{~B}_{1}, \mathrm{~A}_{1} \mathrm{~B}_{2}, \mathrm{~A}_{2} \mathrm{~B}_{1}$, dan $\mathrm{A}_{2} \mathrm{~B}_{2}$.

Perhitungan analisis uji homogenitas distribusi data menggunakan uji Bartlett berdasarkan taraf $\alpha=0,05$ data $\mathrm{Y}$ untuk kelompok $A_{1}$ dan $A_{2}$, kelompok $B_{1}$ dan $B_{2}$, kelompok $\mathrm{A}_{1} \mathrm{~B}_{1}, \mathrm{~A}_{1} \mathrm{~B}_{2}, \mathrm{~A}_{2} \mathrm{~B}_{1}$, dan $\mathrm{A}_{2} \mathrm{~B}_{2}$. Jika hasil pengujian menunjukkan $x^{2}{ }_{\text {hitung }}<x^{2}$ tabel, maka data yang diuji mempunyai varians sama atau homogen. c. Uji Hipotesis

Uji hipotesis yang digunakan adalah analisis varians atau anoma dua arah pada taraf signifikan $\alpha=0,05$. Berikut adalah langkahlangkah dalam perhitungan ANOVA dua jalur (two way ANOVA):

1) Identifikasi nilai: $\mathrm{t}$ (jumlah perlakuan), $\mathrm{r}$ (jumlah blog),

2) hitung jumlah pengamatan total (n), yaitu: $\mathbf{n}$ $=\mathbf{r} \times \mathbf{t}$,

3) Hitung jumlah kuadrat total dengan rumus:

$$
s S_{T}=\sum\left(X_{i j}\right)^{2}-\frac{\left(\sum T_{j}\right)^{2}}{n}
$$

4) Hitung jumlah kuadrat perlakuan dengan rumus:

$$
S S_{P}=\sum \frac{\sum\left(P_{1}\right)^{2}}{r}-\frac{\left(\sum T_{j}\right)^{2}}{n}
$$

5) Hitung jumlah kuadrat antar blok dengan rumus:

$$
S S_{B}=\sum \frac{\sum\left(B_{1}\right)^{2}}{t}-\frac{\left(\sum T_{j}\right)^{2}}{n}
$$

6) Cari harga F-Hitung dengan menggunakan rumus yang tertera pada tabel.

Tabel1. Kalkulasi Perhitungan Anova Dua Jalur (TwoWay Anova)

\begin{tabular}{lcccc}
\hline Sumber Variasi & df & SS & MS & F-HITUNG \\
\hline Antar Blok & $\mathrm{r}-1$ & $S S_{B}$ & $M S_{B}=\frac{S S_{B}}{r-1}$ & $\frac{M S_{B}}{M S_{E}}$ \\
Antar Perlakuan & $\mathrm{t}-1$ & $S S_{p}$ & $M S_{p}=\frac{S S_{p}}{t-1}$ & $\frac{M S_{p}}{M S_{E}}$ \\
$\begin{array}{l}\text { Dalam Perlakuan } \\
\text { (error) }\end{array}$ & $(\mathrm{n}-1)-(\mathrm{k}-1)-(\mathrm{t}-1)$ & $S S_{T}=$ & $S S_{E}$ & \\
\hline \multicolumn{1}{c}{ Total } & $\mathrm{n}-1$ & $S S_{T}-S S_{p}$ & $(\mathrm{r}-1)-(\mathrm{t}-1)$ & \\
\hline
\end{tabular}

7) Cari harga $F$ tabel dengan mempertimbangkan (1) tingkat signifikansi $(\alpha),(2)$ df1 yaitu df dari MS terbesar, dan (3) df2 yaitu df dari MS terkecil.

8) Bandingkan harga $F$ Hitung dengan $F$ tabel. (1) Bila F Hitung < F tabel, maka Ho diterima, yang berarti rata-rata kedua perlakuan tidak berbeda secara signifikan,

(2) Bila F Hitung > F tabel, maka Ho ditolak dan $\mathrm{H} 1$ diterima, yang berarti rata-rata kedua perlakuan berbeda secara signifikan.
Uji hipotesis statistik sebagai berikut :

$\begin{array}{ll}\text { 2. } & \mathrm{H}_{0}: \mu \mathrm{A}_{1} \leq \mu \mathrm{A}_{2} \\ & \mathrm{H}_{1}: \mu \mathrm{A}_{1}>\mu \mathrm{A}_{2} \\ \text { 3. } & \mathrm{H}_{0}: \mu \mathrm{B}_{1} \leq \mathrm{B}_{2} \\ & \mathrm{H}_{1}: \mu \mathrm{B}_{1}>\mathrm{B}_{2} \\ \text { 4. } & \mathrm{H}_{0}: \mathrm{INT} \mathrm{A} X \mathrm{~B}=0 \\ & \mathrm{H}_{1}: \mathrm{INT} \mathrm{A} \mathrm{B}_{\neq} 0 \\ \text { 5. } & \mathrm{H}_{0}: \mu \mathrm{A}_{1} \mathrm{~B}_{1}<\mathrm{A}_{2} \mathrm{~B}_{1} \\ & \mathrm{H}_{1}: \mu \mathrm{A}_{1} \mathrm{~B}_{1}>\mathrm{A}_{2} \mathrm{~B}_{1} \\ \text { 6. } & \mathrm{H}_{0}: \mu \mathrm{A}_{1} \mathrm{~B}_{2} \geq \mathrm{A}_{2} \mathrm{~B}_{2} \\ & \mathrm{H}_{1}: \mu \mathrm{A}_{1} \mathrm{~B}_{2}<\mathrm{A}_{2} \mathrm{~B}_{2} \\ \text { 7. } & \mathrm{H}_{0}: \mu \mathrm{A}_{1} \mathrm{~B}_{1} \leq \mathrm{A}_{1} \mathrm{~B}_{2}\end{array}$




$$
\begin{array}{ll} 
& \mathrm{H}_{1}: \mu \mathrm{A}_{1} \mathrm{~B}_{1}>\mathrm{A}_{1} \mathrm{~B}_{2} \\
\text { 8. } & \mathrm{H}_{0}: \mu \mathrm{A}_{2} \mathrm{~B}_{1} \geq \mathrm{A}_{2} \mathrm{~B}_{1} \\
& \mathrm{H}_{1}: \mu \mathrm{A}_{2} \mathrm{~B}_{1}<\mathrm{A}_{2} \mathrm{~B}_{1}
\end{array}
$$

a. Uji lanjut

Apabila terdapat interaksi dalam penelitian ini, maka langkah selanjutnya adalah menggunakan analisis dengan Uji Tukey antara model pembelajaran TGT terhadap hasil belajar IPS siswa.

\section{HASIL PENELITIAN}

\section{Hasil}

Berdasarakan hasil perhitungan pengujian hipotesis dapat disimpulkan bahwa:

1) Terdapat perbedaan hasil belajar IPS yang menggunakan model pembelajaran TGT dan metode ceramah bervariasi.

Berdasarkan hasil perhitungan ANOVA dapat diketahui bahwa nilai hasil pengujian hipotesis yang disajikan dalam Tabel ANOVA pada baris Antar A menunjukkan bahwa secara keseluruhan bahwa $\mathrm{F}_{\text {hitung }}=7,48>\mathrm{F}_{\text {tabel }}=4,02$ dengan taraf signifikan 0,05 .

Rangkuman hasil perhitungan perbedaan antar dua kelompok (Antar A) dapat dilihat pada Tabel 4.15 sebagai berikut :

Tabel 4.15 : Rangkuman hasil perhitungan $\left(A_{1} \& A_{2}\right)$.

\begin{tabular}{c|c|c|c|c}
\hline No & $\begin{array}{c}\text { Kelompok yang } \\
\text { dibandingkan }\end{array}$ & $\mathbf{Q}_{\text {hitung }}$ & $\mathbf{Q}_{\text {tabel 0,05 }}$ & Keterangan \\
\hline 1 & $\mathrm{~A}_{1} \& \mathrm{~A}_{2}$ & 3,93 & 2,89 & Signifikan \\
\hline
\end{tabular}

Berdasarkan Tabel 4.15 menunjukkan hasil perhitungan antar dua kelompok tentang perbedaan keefektifan antara kedua model pembelajaran secara keseluruhan bahwa $\mathrm{Q}_{\text {hitung }}=$ $3,93>\mathrm{Q}_{\text {tabel }}=2,89$ pada taraf Signifikan $\alpha=0.05$, dengan demikian $\mathrm{H}_{0}$ ditolak dan hipotesis alternatif $\mathrm{H}_{1}$ diterima. Maka hasil belajar IPS antara kelompok siswa yang diberikan model TGT lebih tinggi dibandingkan dengan kelompok siswa yang diberikan Ceramah bervariasi.

Hasil Perhitungan ANAVA 2 × 2 dapat disimpulkan bahwa terdapat perbedaan pengaruh yang signifikan antara kelompok siswa yang diberikan model TGT dan kelompok siswa yang diberikan ceramah bervariasi terhadap hasil belajar IPS. Oleh karena itu, hasil belajar IPS yang diberikan model TGT ( $\bar{X}=41,7$ dan $\mathrm{s}=$ $4,06)$ lebih baik secara nyata dibandingkan yang diberikan ceramah bervariasi ( $\bar{X}=39,63$ dan s
$=3,10)$. Hal ini berarti hipotesis penelitian secara keseluruhan adalah hasil belajar IPS yang diberikan model TGT lebih tinggi dibandingkan dengan kelompok siswa yang diberikan ceramah bervariasi.

\section{2) Terdapat perbedaan hasil belajar IPS pada siswa motivasi tinggi dan siswa motivasi rendah.}

Berdasarkan hasil perhitungan ANAVA dapat diketahui bahwa nilai hasil pengujian hipotesis yang disajikan dalam Tabel ANAVA pada baris Antar Bmenunjukkan bahwa secara keseluruhan bahwa $\mathrm{F}_{\text {hitung }}=12,55>\mathbf{F}_{\text {tabel }}=4,02$ pada taraf signifikan 0,05 .

Rangkuman hasil perhitungan antar dua kelompok (Antar B) dapat dilihat pada Tabel 4.16 sebagai berikut :

Tabel 4.16 : Rangkuman hasil perhitungan $\left(B_{1} \& B_{2}\right)$.

\begin{tabular}{c|c|c|c|c}
\hline No & $\begin{array}{c}\text { Kelompok yang } \\
\text { dibandingkan }\end{array}$ & $\mathbf{Q}_{\text {hitung }}$ & $\mathbf{Q}_{\text {tabel 0,05 }}$ & Keterangan \\
\hline 1 & $\mathrm{~B}_{1} \& \mathrm{~B}_{2}$ & 5,58 & 2,89 & Signifikan \\
\hline
\end{tabular}

Berdasarkan Tabel 4.16 menunjukkan hasil perhitungan antar dua kelompok tentang perbedaan keefektifan antara kedua motivasi belajar secara keseluruhan bahwa $\mathrm{Q}_{\text {hitung }}=5,58$ 
$>\mathrm{Q}_{\text {tabel }}=4,02$ pada taraf Signifikan $\alpha=0.05$, dengan demikian $\mathrm{H}_{0}$ ditolak dan hipotesis alternatif $\mathrm{H}_{1}$ diterima. Maka hasil belajar IPS antara kelompok siswa yang memiliki Motivasi belajar Tinggi dan kelompok yang Motivasi belajar rendah..

Hasil Perhitungan ANOVA 2 × 2 dapat disimpulkan bahwa terdapat perbedaan pengaruh yang signifikan antara kelompok siswa yang memiliki Motivasi belajar Tinggi dan kelompok yang Motivasi belajar rendahterhadap hasil belajar IPS. Oleh karena itu, hasil belajar IPS yang memiliki Motivasi belajar Tinggi ( $\bar{X}$ $=42,27$ dan $\mathrm{s}=3,47$ ) lebih baik secara nyata dibandingkan yang memiliki Motivasi belajar rendah ( $\bar{X}=39,33$ dan $\mathrm{s}=3,33$ ). Hal ini berarti hipotesis penelitian secara keseluruhan adalah hasil belajar IPS yang memiliki Motivasi belajar Tinggi lebih tinggi dibandingkan dengan kelompok siswa yang memiliki Motivasi belajar rendah.

3) Terdapat Perbedaan hasil belajar IPS kelompok yang menggunakan model pembelajaran TGT dan kelompok yang menggunakan metode ceramah bervariasi pada siswa motivasi tinggi.

Rangkuman hasil perhitungan Uji Lanjut Tukey dapat dilihat pada Tabel 4.17 sebagai berikut :

Tabel 4.17: Rangkuman hasil perhitungan Uji Tukey $\left(A_{1} B_{1} \& A_{2} B_{1}\right)$.

\begin{tabular}{c|c|c|c|c}
\hline No & $\begin{array}{c}\text { Kelompok yang } \\
\text { dibandingkan }\end{array}$ & $\mathbf{Q}_{\text {hitung }}$ & $\mathbf{Q}_{\text {tabel 0,05:4:15 }}$ & Keterangan \\
\hline 1 & $\mathrm{~A}_{1} \mathrm{~B}_{1} \& \mathrm{~A}_{2} \mathrm{~B}_{1}$ & 7,44 & 4,08 & Signifikan \\
\hline
\end{tabular}

Berdasarkan Tabel 4.17 menunjukkan bahwa perhitungan Uji Tukey $\mathrm{A}_{1} \mathrm{~B}_{1}>\mathrm{A}_{2} \mathrm{~B}_{1}=\mathrm{Q}_{\text {hitung }}$ $=7,44$ lebih besar dari pada $\mathrm{Q}_{\text {tabel 0,05:4:15 }}=4,08$ atau $\mathrm{Q}_{\text {hitung }}>\mathrm{Q}_{\text {tabel }}$ pada taraf Signifikan $\alpha=0.05$, dengan demikian $\mathrm{H}_{0}$ ditolak dan hipotesis alternatif $\mathrm{H}_{1}$ diterima. Sehingga dapat ditafsirkan hasil belajar IPS antara kelompok siswa yang diberikan model TGT lebih tinggi dibandingkan dengan kelompok siswa yang diberikan ceramah bervariasi.

Oleh karena itu, bagi siswa yang memiliki kemampuan literasi membaca tinggi yang diberikan model TGT ( $\bar{X}=45$ dan s $=$ $2,15)$ lebih tinggi secara nyata dibandingkan yang diberikan ceramah bervariasi ( $\bar{X}=38,6$ dan $\mathrm{s}=2,89$ ). Hal ini berarti hipotesis penelitian kelompok yang memiliki kemampuan motivasi belajar tinggi yang diberikan model TGT lebih tinggi dibandingkan dengan yang diberikan ceramah bervariasi terhadap hasil belajar IPS.

4) Terdapat perbedaan hasil belajar IPS kelompok yang menggunakan model pembelajaran TGT dan kelompok yang menggunakan metode ceramah bervariasi pada siswa motivasi rendah.

Rangkuman hasil perhitungan Uji Tukey dapat dilihat pada Tabel 4.18 sebagai berikut :

Tabel 4.18 : Rangkuman hasil perhitungan Uji Tukey $\left(A_{1} B_{2} \& A_{2} B_{2}\right)$.

\begin{tabular}{c|c|c|c|c}
\hline No & $\begin{array}{c}\text { Kelompok yang } \\
\text { dibandingkan }\end{array}$ & $\mathbf{Q}_{\text {hitung }}$ & $\mathbf{Q}_{\text {tabel 0,05:4:15 }}$ & Keterangan \\
\hline 1 & $\mathrm{~A}_{1} \mathrm{~B}_{2} \& \mathrm{~A}_{2} \mathrm{~B}_{2}$ & 1,97 & 4,08 & Signifikan \\
\hline
\end{tabular}

Berdasarkan Tabel 4.18 menunjukkan bahwa perhitungan Uji Tukey $\mathrm{A}_{1} \mathrm{~B}_{2}<\mathrm{A}_{2} \mathrm{~B}_{2}=\mathrm{Q}_{\text {hitung }}$ $=1,97$ lebih kecil dari pada $\mathrm{Q}_{\text {tabel } 0,05: 4: 10}=4,08$ atau $\mathrm{Q}_{\text {hitung }}<\mathrm{Q}_{\text {tabel }}$ pada taraf Signifikan $\alpha=0.05$, dengan demikian $\mathrm{H}_{0}$ ditolak dan hipotesis alternatif $\mathrm{H}_{1}$ diterima. Sehingga dapat disimpulkan bahwa hasil belajar IPS antara kelompok siswa yang diberikan model TGT rendah dibandingkan dengan kelompok siswa yang diberikan ceramah bervariasi.

Oleh karena itu, bagi siswa yang memiliki kemampuan motivasi belajar rendah yang diberikan model TGT ( $\bar{X}=38,6$ dan $\mathrm{s}=$ $2,89)$ lebih rendah secara nyata dibandingkan yang diberikan ceramah bervariasi ( $\bar{X}=40,1$ dan $\mathrm{s}=3,67)$. Hal ini berarti hipotesis penelitian 
kelompok yang memiliki kemampuan motivasi belajar rendah yang diberikan model TGT lebih rendah dibandingkan dengan yang diberikan ceramah bervariasi terhadap hasil belajar IPS.

5) Terdapat perbedaan hasil belajar IPS siswa motivasi tinggi dan siswa motivasi rendah pada kelas yang menggunakan model pembelajaran TGT.

Perhitungan analisis varians tahap lanjut dengan Uji Tukey adalah untuk membandingkan kelompok yang memiliki kemampuan motivasi belajar tinggi yang diberikan model TGT dan yang diberikan ceramah bervariasi. Rangkuman hasil perhitungan Uji Lanjut Tukey dapat dilihat pada Tabel 4.19 sebagai berikut :

Tabel 4.19 : Rangkuman hasil perhitungan Uji Tukey $\left(\mathrm{A}_{1} \mathrm{~B}_{1} \& \quad \mathrm{~A}_{1} \mathrm{~B}_{2}\right)$.

\begin{tabular}{|c|c|c|c|c|}
\hline $\mathbf{N}$ & $\begin{array}{c}\text { Kelompok } \\
\mathbf{y a n g} \\
\text { dibandingka } \\
\mathbf{n}\end{array}$ & $\begin{array}{c}\mathbf{Q}_{\text {hitun }} \\
\mathbf{g}\end{array}$ & $\begin{array}{c}\mathbf{Q}_{\text {tabel }} \\
\mathbf{0 , 0 5 : 4 : 1}\end{array}$ & $\begin{array}{c}\text { Keteranga } \\
\mathbf{n}\end{array}$ \\
\hline 1 & $\mathrm{~A}_{1} \mathrm{~B}_{1} \& \mathrm{~A}_{1} \mathrm{~B}_{2}$ & 8,25 & 4,08 & Signifikan \\
\hline
\end{tabular}

Berdasarkan Tabel 4.19 menunjukkan bahwa perhitungan Uji Tukey $\mathrm{A}_{1} \mathrm{~B}_{1}>\mathrm{A}_{2} \mathrm{~B}_{1}=\mathrm{Q}_{\text {hitung }}$ $=8,25$ lebih besar dari pada $\mathrm{Q}_{\text {tabel } 0,05: 4: 15}=4,08$ atau $\mathrm{Q}_{\text {hitung }}>\mathrm{Q}_{\text {tabel }}$ pada taraf Signifikan $\alpha=0.05$, dengan demikian $\mathrm{H}_{0}$ ditolak dan hipotesis alternatif $\mathrm{H}_{1}$ diterima. Sehingga dapat ditafsirkan hasil belajar IPS antara kelompok siswa yang memiliki motivasi belajar tinggi lebih tinggi dibandingkan dengan kelompok siswa yang memiliki motivasi belajar rendah.

Oleh karena itu, bagi siswa yang memiliki kemampuan motivasi belajar tinggi yang diberikan model TGT ( $\bar{X}=45$ dan $\mathrm{s}=$ $2,15)$ lebih tinggi secara nyata dibandingkan yang diberikan ceramah bervariasi ( $\bar{X}=39$ dan $\mathrm{s}=2,45)$. Hal ini berarti hipotesis penelitian kelompok yang memiliki kemampuan motivasi belajar tinggi yang diberikan model TGT lebih tinggi dibandingkan dengan motivasi belajar rendah yang diberikan ceramah bervariasi terhadap hasil belajar IPS.

6) Terdapat perbedaan hasil belajar IPS siswa motivasi tinggi dan siswa motivasi rendah pada kelas yang menggunakan metode ceramah bervariasi.

Perhitungan analisis varians tahap lanjut dengan Uji Tukey adalah untuk membandingkan kelompok yang memiliki kemampuan motivasi belajar rendah yang diberikan kelompok TGT dan kelompok ceramah bervariasi Rangkuman hasil perhitungan Uji Tukey dapat dilihat pada Tabel 4.20 sebagai berikut :

Tabel 4.20 : Rangkuman hasil perhitungan Uji Tukey $\left(\mathrm{A}_{1} \mathrm{~B}_{2} \& \mathrm{~A}_{2} \mathrm{~B}_{2}\right)$.

\begin{tabular}{|c|c|c|c|c|}
\hline $\begin{array}{c}\mathbf{N} \\
\mathbf{0}\end{array}$ & $\begin{array}{c}\text { Kelompok } \\
\text { yang } \\
\text { dibandingka } \\
\mathbf{n}\end{array}$ & $\begin{array}{c}\mathbf{Q}_{\text {hitun }} \\
\mathbf{g}\end{array}$ & $\begin{array}{c}\mathbf{Q}_{\text {tabel }} \\
\mathbf{0 , 0 5 : 4 : 1} \\
\mathbf{5}\end{array}$ & $\begin{array}{c}\text { Keteranga } \\
\mathbf{n}\end{array}$ \\
\hline 1 & $\mathrm{~A}_{2} \mathrm{~B}_{1} \& \mathrm{~A}_{2} \mathrm{~B}_{2}$ & 1,17 & 4,08 & Signifikan \\
\hline
\end{tabular}

Berdasarkan Tabel 4.20 menunjukkan bahwa perhitungan Uji Tukey $\mathrm{A}_{1} \mathrm{~B}_{2}<\mathrm{A}_{2} \mathrm{~B}_{2}=\mathrm{Q}_{\text {hitung }}$ $=1,17$ lebih kecil dari pada $\mathrm{Q}_{\text {tabel 0,05:4:10 }}=4,08$ atau $\mathrm{Q}_{\text {hitung }}<\mathrm{Q}_{\text {tabel }}$ pada taraf Signifikan $\alpha=0.05$, dengan demikian $\mathrm{H}_{0}$ ditolak dan hipotesis alternatif $\mathrm{H}_{1}$ diterima. Sehingga dapat disimpulkan bahwa hasil belajar IPS antara kelompok siswa yang diberikan motivasi belajar tinggi lebih rendah dibandingkan dengan keleompok siswa yang memiliki motivasi belajar rendah.

Oleh karena itu, bagi siswa yang memiliki kemampuan motivasi belajar rendah yang diberikan model TGT keefektifan motivasi belajar tinggi ( $=39$ dan $\mathrm{s}=2,45$ ) lebih rendah secara nyata dibandingkan yang memiliki motivasi rendah ( $=40$ dan $\mathrm{s}=3,67)$. Hal ini berarti hipotesis penelitian kelompok yang memiliki kemampuan motivasi belajar tinggi yang diberikan ceramah bervariasi lebih rendah dibandingkan dengan yang diberikan modelTGT terhadap hasil belajar IPS.

7) Terdapat interaksi antara model pembelajaran dengan motivasi belajar siswa terhadap hasil belajar IPS (INT A X B).

Berdasarkan hasil perhitungan ANOVA dapat diketahui bahwa nilai hasil pengujian 
hipotesis kedua yang disajikan dalam Tabel ANAVA pada baris Interaksi A $X$ menunjukkan bahwa $\mathrm{H}_{0}$ ditolak berdasarkan nilai $\mathrm{F}_{\text {hitung }}=22,2>\mathrm{F}_{\text {tab }(0,05: 1: 55)}=4,02$, dengan demikian dapat diambil keputusan bahwa terdapat pengaruh interaksi yang signifikan antara model pembelajaran dan motivasi belajar terhadap hasil belajar IPS.

Berdasarkan data hasil penelitian, pengaruh interaksi diperoleh jika pengujian $F_{\text {hitung }}>F_{\text {tabel }}$ pada taraf signifikan yang diipilih dengan db pembilang adalah 1 maka $\mathrm{F}_{\text {tabel }}: \alpha=$ 0.05 adalah4,02maka $\mathrm{H}_{0}$ ditolak $\mathrm{H}_{1}$ diterima. Ini berarti bahwa $\mathrm{F}_{\text {hitung }}=22,2>\mathrm{F}_{\mathrm{tab}(0,05 ; 1 ; 55)}=4,02$ maka $\mathrm{H}_{0}$ ditolak $\mathrm{H}_{1}$ diterima.Dengan demikian ada pengaruh interaksi yang signifikan antar faktor model pembelajaran dan motivasi belajar terhadap hasil belajar IPS.

Rangkuman hasil perhitungan data melalui ANOVA 2x2 dapat dilihat pada Gambar 4.9 sebagai berikut :

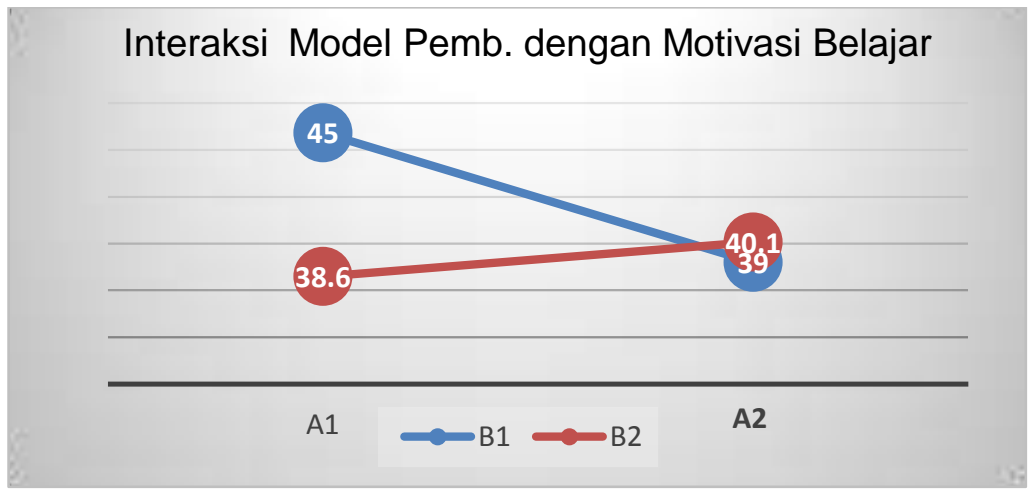

\section{Gambar 4.9: Interaksi Bentuk Model Pembelajaran dan Motivasi Belajar.}

\section{Keterangan :}

$\mathrm{A}_{1}=$ Model TGT

$\mathrm{A}_{2}=$ Ceramah Bervariasi

$\mathrm{B}_{1}=$ Motivasi Belajar Tinggi

$\mathrm{B}_{2}=$ Motivasi Belajar Rendah

Hal ini berarti hipotesis penelitian terdapat pengaruh interaksi bentuk model pembelajaran dengan motivasi belajar terhadap hasil belajar IPS.

\section{Pembahasan}

Hasil belajar IPS merupakan hasil proses belajar yang mempelajari mengenai halhal yang berkaitan dengan kehidupan sosial. Untuk menunjang suatu keberhasilan hasil belajar IPS Kelas V di sekolah Dasar, Model TGT sangat penting digunakan dalam proses pembelajaran yang merupakan sebagai model pembelajaraan yang dapat menunjang keberhasilan anak. Untuk mendapatkan kemampuan hasil belajar IPS yang baik diperlukan suatu model pembelajaran yang dapat dijadikan sebagai salah satu model pembelajaran yang dapat memotivasi untuk lebih aktif, kreatif dan mandiri dalam proses belajar mengajar. Hal ini sangat diperlukan untuk dapat membantu menyampaikan materi pembelajaran melalui model pembelajaran yang berbasis model TGT yang dapat menghasilkan suatu hasil belajar IPS yang baik. Untuk itu dibutuhkan model pembelajaran TGT dalam meningkatkan hasil belajar IPS.Dalam penelitian ini diterapkan model TGT dan ceramah bervariasi dengan tujuan meningkatkan hasil belajar IPS.

Pelaksanaan model pembelajaran ini menerapkan model TGT. Model TGT lebih mengutamakan keaktifan siswa sehingga dapat memahami materi dengan lebih baik sehingga Siswa lebih percaya diri untuk untuk berfikir mandiri, menemukan informasi dari berbagai sumber, dan belajar bersama siswa lainnya, Mengembangkan kemampuan mengungkapkan ide secara verbal dan membandingkan dengan ide-ide orang lain, Menumbuhkan sikap respon terhadap orang lain, Membantu memberdayakan setiap siswa untuk lebih bertanggung jawab dalam belajar, Meningkatkan prestasi akademik dan kemampuan sosial, Meningkatkan kemampuan siswa menggunakan informasi dan mengubah belajar abstrak menjadi nyata.

Sesuai dengan sintaks model pembelajaran TGT yang dikemukakan oleh Rahmat (2007:1) yaitu penyajian kelas dimana diawali dengan guru 
menyampaikan materi pembelajaran IPS lalu dalam hal ini siswa dikelompokkan dalam sebuah kelompok belajar atau team yang terdiri dari 4 sampai 5 orang . fungsi kelompok adalah untuk lebih mendalami materi bersama teman kelompoknya dan lebih khusus untuk mempersiapkan anggota kelompok agar bekerjasama dengan baik. Setelah dikelompokkan lalu guru mengadakan games yang terdiri dari pertanyaan bernomor dan siswa menjawab pertanyaan tersebut . siswa yang menjawab pertanyaan dengan benar maka akan diberi skor lalu dikumpulkan untuk tournament mingguan. Tournament dilakukan untuk membantu memotivasi siswa dalam belajarnya sehingga mampu meningkatkan hasil belajar siswa. Pada tahap akir guru memberikan pengharaan berdasarkan rerata point yang diperoleh dar pemain. Berdasarkan model pembelajaran TGT yang telah dilakukan maka peneliti menyimpulkan bahwa model pembelajaran TGT mampu meningkatkan hasil belajar siswa sebab pembelajaran TGT mampu memotivasi siswa secara baik sehingga berpengaruh positif terhadap hasil belajar siswa adapun siswa yang tidak mampu mengiuti tahapan pembelajran TGT yaitu siswa yang kurang motivasi dalam pembelajaran tersebut karena tidak semua siswa mampu mengikuti pembelajaran TGT secara baik yaitu mereka yang kurang motivasi dalam belajar.

Diketahui bahwa Motivasi belajar merupakan sesuatu keadaan yang terdapat pada diri seseorang individu dimana ada suatu dorongan untuk melakukan sesuatu guna mencapai tujuan. Karena itu, untuk menunjang suatu keberhasilan hasil belajar IPS Kelas V di sekolah Dasar, motivasi belajar sangat penting dalam proses pembelajaran yang dapat menunjang keberhasilan anak. Untuk mendapatkan kemampuan hasil belajar IPS yang baik diperlukan juga motivasi belajar yang dapat dijadikan sebagai dorongan untuk belajar.Dengan mengetahui hasil belajar IPS, anak didik terdorong untuk belajar lebih giat. Apalagi bila hasil belajar itu mangalami kemajuan, anak didik berusaha untuk mempertahankannya atau bahkan meningkatkan intensitas belajarnya guna mendapatkan prestasi belajar yang lebih baik sehingga dapat dijadikan sebagai alat motivasi dalam meningkatkan hasil belajar IPS.
Salah satu motivasi belajar yang dapat meningkatkan motivasi belajar apabila motivasi belajar anak tinggi dapat menghasilkan suatu hasil belajar IPS yang baik. Untuk itu dibutuhkan motivasi belajar dalam meningkatkan hasil belajar IPS. Hal ini membuktikan bahwa terdapat interaksi antara model pembelajaran TGT dengan motivasi belajar sebab melalui motivasi belajar mampu meningkatkan hasil belajar IPS siswa sekolah dasar.

Dikatakan bahwa siswayang memiliki motivasi belajar tinggi dan motivasi belajar rendah ini mempunyai tujuan yang sama dalam meningkatkan hasil belajar IPS, tetapi samasama memiliki perbedaan dalam segi proses pembelajaran. Bagi yang memiliki kemampuan motivasi belajar tinggi menerapkan model TGT memberikan adanya usaha yang tekun dan didasari motivasi maka siswa akan belajar dengan baik dan prestasi belajar akan optimal. Kelompok Motivasi belajar tinggi merupakan sesuatu keadaan yang terdapat pada diri seseorang individu dimana ada suatu dorongan untuk melakukan sesuatu guna mencapai tujuan. Sedangkan siswa yang memiliki motivasi rendah akan kesulitan dalam proses pembelajaran TGT sebab mereka kesulitan mengikuti pembelajaran tersebut karena kurangnya usaha yang mereka lakukan dalam proses pembelajaran itu sedangan dalam pembelajaran TGT dibutuhkan usaha yang lebih dalam pembelajarannya.

\section{SIMPULAN DAN SARAN}

Berdasarkan hasil temuan dalam penelitian ini maka dapat disimpulkan bahwa hasil belajar IPS yang diajar dengan menggunakan model pembelajaran TGT lebih tinggi dari pada metode ceramah bervariasi dan hasil belajar IPS pada siswa motivasi tinggi lebih tinggi dari pada siswa motivasi rendah serta terdapat pengaruh interaksi antara model pembelajaran dengan motivasi belajar siswa terhadap hasil belajar IPS.

Hasil belajar IPS kelompok yang diajar dengan menggunakan model pembelajaran TGT lebih tinggi dari pada kelompok yang menggunakan metode ceramah bervariasi pada siswa motivasi tinggi dan hasil belajar IPS kelompok yang menggunakan model pembelajaran TGT lebih rendah dari pada kelompok yang menggunakan metode ceramah bervariasi pada siswa motivasi rendah dan hasil belajar IPS siswa motivasi tinggi lebih tinggi dari pada siswa motivasi rendah pada kelas yang 
menggunakan model pembelajaran TGT serta hasil belajar IPS siswa motivasi tinggi lebih rendah dari pada siswa motivasi rendah pada siswa yang diajar dengan menggunakan metode ceramah bervariasi.

Berdasarkan penelitian ini diharapkan guru menggunakan model pembelajaran TGT (Team Games Tournament) dalam proses pembelajaran guna meningkatkan hasil belajar siswa.

\section{DAFTAR RUJUKAN}

Djaali.2010. Konsep Dasar dan Pokok-Pokok Desain Eksperimen. Jakarta: Pascasarjana Universitas Negeri Jakarta.

Gan, Teck Hock. 2006. Menangani Masalah Penguasaan asas Matenatik Melalui Pembelajaran kooperatif (online) (http://www.mpbl.edu.my/math/peda gogi/TGT. (diakses 28 April 2015)

Handini, Myrnawati Crie. 2012.Metodelogi Penelitian Untuk Pemula. Jakarta: FIP Press.

Kadir. 2010. Statistika Untuk Penelitian IlmuIlmu Sosial. Jakarta: Rosemata Sampurna.

Rahmat, Jalaluddin. 2007. Persepsi dalam Proses Belajar Mengajar. Jakarta: Rajawali Pers.

Suradi. 2011. Skenario Pembelajaran. Jakarta: Kencana Preana Media Group.

Suryosubroto, B. 2005. Proses Belajar Mengajar Di Sekolah. Jakarta: Rineka Cipta.

Wasliman. 2007. Problematika Pendidikan Dasar. Jakarta: Bumi Aksara. 